\title{
The Role of the Government in the Karo Regency Assists Farmers to Face the Crisis of Agricultural Production in the Pandemic of Covid-19
}

\author{
Alfon Octavianus Sitepu ${ }^{1}$, Faisal Santiago ${ }^{2}$, Ricky Purwanto ${ }^{3}$ \\ \{Advokat.alfonsitepu@gmail.com ${ }^{1}$,Faisal_Santiago@yahoo.co.id ${ }^{2}$, Rickypoerwanto1974@gmail.com 3 \} \\ Universitas Borobudur, Jakarta ${ }^{1,2,3}$
}

\begin{abstract}
Pandemic Covid-19 poses a negative impact on all aspects of human life around the world. Since the widespread transmission of covid-19 in March 2019, almost every business in the world is experiencing a decline in production, some even closing their doors for lack of income. This is due to an imbalance between income and the cost of production. Especially in the field of agricultural products, raw materials for food and the nine basic human needs also experienced a negative impact, to the detriment of many farmers. The main impact that is being experienced is the rising price of fertilizer and pesticide prices, as well as the price of plant seedsbecause the plant that gives supply to many farmers has stopped operating due to the employees affected by the virus. This has caused the composition of the supply of goods to demand to be unbalanced, causing the price to soar. The next problem does not stop everywhere agricultural production, but problems arise in the marketing of agricultural products where the selling price given by farmers to consumers is in tune with the rising cost of production, with equally raising the selling price. Against the increase in prices of agricultural products, such as consumers who are also experiencing the negative impact of the pandemic covid-19, take measures to reduce spending activities that are not necessary and only focus on the needs of the principal course. Suppose the conditions before the pandemic covid-19, there were still many people who consumed rice, vegetables, fish, meat, eggs, chicken, milk, fruits, herbal medicine, and so on, because regular income is still there for the shopping needs of day-to-day, while after the In this position, the role of the government in providing solutions to farmers is expected to provide training and knowledge so that the farmers can obtain a second opinion on creating an alternative fertilizer, pesticides, and nursery/nursery itself, which can ultimately reduce the cost of production and can be independent in conducting the needs of agricultural production once the pandemic covid-19 is over and all the economic activity is back to normal.
\end{abstract}

Keywords: Pandemic; Agricultural; Production

\section{Introduction}


The state of Indonesia is thought of as an Agrarian Country within the presence of all countries of the globe, where the number of farms became the majority as the livelihood of the people in Indonesia. The quality and quantity of agriculture are not separated from the role of stakeholders in agriculture, one of which is the government. Need for agricultural extension fieldbecomes very important to remember the human resources/many farmers are still relying on the traditional knowledge is very limited, considering that the current quality of the soil, seeds, fertilizer is not as good as before, and the number of plant diseases and pests increasingly diverse of its kind. Karo district located in North Sumatra Province is located between $2^{\circ} 50^{`}-3^{0} 19^{`} \mathrm{LU}$ and $97^{0} 55^{\circ}-98^{0} 28^{\prime} \mathrm{BT}$ with the total area of the region 212.725 ha or $2.97 \%$ from the total area of the Province of North Sumatra, have the northern boundary with the District of Langkat, and DeliSerdang Regency, the eastern boundary with the Simalungun Regency and Deli Serdang Regency, the Southern boundary with Dairi Regency and Toba Samosir Regency, the Western boundary with the Southeast Aceh (Aceh Province). Karo regency is a region with the majority of the population work as farmers, with the number of wetland 14.500 ha and the amount of land area gardens/fields of 109.595 ha (source department of agriculture districts curry 2020).

Improving the quality of human resource farmers can be achieved through counseling asan effort to increase knowledge and change the behavior of the farmer with his family to understand, to have the desire and capacity in the search for solutions to achieve maximum results on the business of his farm. At the beginning of the year 2019 happening event of pandemic coronavirus 2019 (covid-19) around the world and resulted in the crisis of a multidimensional one of them towards Indonesia. The impact of a multidimensional crisis is one of them because the utility of the economic activity only runs a maximum of $25 \%$ as a result of the program PPKM imposed by the government to limit the transmission of covid-19. The other impact is the entire cost of the construction of many diverted to support an emergency fund in the face of pandemic covid-19, including the cost of construction for agricultural extension to be reduced. Thegovernment of Karo Regency can be said to make the investment areas appropriate if an agricultural extension can cultivate the qualities of farmers in the Karo Regency. In the regulation of a team of responsible government in agricultural extension is the Department of Agriculture and Plantation, Department of Forestry, Department of Animal Husbandry and Fisheries, the Agency for the Implementation of Agricultural Extension, Fisheries, and Forestry / BP4K.[1]

In Indonesia, there are regulations that a special form of Act No. 16 of 2006 about the System of Agricultural Extension, Fisheries and Forestry, which perceives counseling as an effort in improving the intelligence of the nation to create a welfare society with the build of agriculture, fisheries and forestry in a sustainable way and to be important to food security, board, and raw materials industry can be achieved.[2] Since 2001 the activities of the agricultural extension have been submitted entirely to the local government following with the regulations governing decentralization, namely Law Number 32 the Year 2004 on Regional Autonomy, which was revised by Act Number 23 the Year 2014 on Regional Autonomy. As the implementation of LawNo. 16 of 2006, has formed the counseling at the Provincial level in the form of Body Coordination of Agricultural Extension, Fisheries, and Forestry (BAKORLUH), then the level of District/City in the form of the Executive Agency for Agricultural Extension, Fisheries, and Forestry (BP4K), as well as the District level in the form of Extension institute of Agriculture, Fisheries and Forestry (BP3K).[3] Based on data obtained from the Counseling and Human ResourceDevelopment of Agriculture, the number of agricultural extension workers in the District of Karoas much as 386 people the period of 2019 up to now consisting of 40 people the status of civil servants, 96 people were the Most Daily 
Off, and 250 people the status of non-governmental organizations.

The positive impact that obtained with the shift to the area is the monitoring and the needsof agricultural extension can be adapted to the conditions that occur in the life of a farmer, but there are also negative impacts that often occur in the form of differences in perceptions between legislative of local with the executive/Karo regency about the meaning and role of agricultural extension to regional development, and budget the cost of the implementation of agricultural extension is still a little/small, agricultural information in Agricultural Extension Center inadequateabout the price of the market, technology, and others, as well as the ability agricultural extension declining because rarely do face-to-face with farmers for agricultural extension.[4] The construction of Karo can be done if the quality of the people is growing, and the majority of the population Karo is a farmer, it is the essence of the importance of agricultural extension as a step of non- formal education to educate the community to develop the ability/skill in the environment so that it becomes the present Government of Karo Regency to develop regional development.

Against the above-mentioned conditions, the researchers in this paper want to know howthe view of the Government of Karo on the implementation of agricultural extension in the Karo District? as well as the obstacles faced during the conduct of agricultural extension in Karo District? So, through this paper, the citizens of the community can increase their knowledge aboutthe activities of counseling, and to the students can add insight their knowledge against agricultural extension activities, as well as against the government can be advice in taking the policy in the repair extension activities in the foreseeable future.

\section{Method}

Normative law research uses normative case studies in the form of legal behavioral products, such as reviewing the Law. The point of the study is the law that is conceptualized as anorm or rule that behaves in society and becomes a reference to every one's behavior. So normative legal research focuses on the inventory of positive laws, legal principles and doctrines, the discovery of law in cases in concreto, systematic law, synchronization standards, comparativelaws, and legal history. The method of approach in this research is the approach of the invitation regulation (statue approach). A normative research must certainly use the invitation-invite approach because what will be researched is the various rule of law that becomes the focus as well as the central theme of a study. The data source used to be processed in normative legal research is secondary data, i.e. the study of documents or literature by collecting and examining or researching documents and libraries that can provide information or information needed by researchers.

\section{Discussion}

Regional development through agriculture is a social process that aims to improve the quality of farmers, their welfare, and also to maintain the availability of the potential of local natural resources in a sustainable manner so that it has a positive value in the economic, social, political, cultural, and can be carried out continuously to get the growth and repair. The development of good agricultural includes: are the results of the farm, there is appropriate technology, availability of materials and equipment from local, as well as the available means oftransport.[5] Good farming can give a positive value to the availability of 
Gross Domestic Product/GDP, income, foreign exchange, food security, board and raw material needs of the industry, open jobs, and add to the income of the community.[6] The founder of the nation of Indonesia are aware that agriculture in Indonesia is an important pillar, and the Father of Indonesia's first President, Ir Sukarno delivered a continuation of Farmer's as a Buffer State Order Indonesia in 1952, where agricultural development is done gradually, namely the development of the agricultural sector and the means of agricultural production, and the development of agro-processing the results of agricultural enterprises.[7]

Act No. 16 of 2006 about the System of Agricultural Extension, Fisheries, and Forestry, lays out the definition of counseling as a process of learning for the main actors as well as the businesses that they are willing and able to help and organize itself in accessing market information, technology, capital, and other resources, to improve productivity, efficiency, revenue, and welfare, as well as raise awareness in the preservation of environmental functions. Therefore, agricultural extension to get an important place in improving the welfare and participation of the main actors in development in the region and nationally. In the implementation of counseling, it is expected to achieve 2 goals, namely the short term in the form of bringing change to the farmers to knowledge, ability, and behavior of farmers, while the purpose of the Long term in the form of an increase in the standard of life and well-being of farmers. By following the agricultural extension every farmer will be better able to Pratik agricultural good, profitable, prosperous and environmentally clean and healthy.

According to Article 46 of the letter H Regulations Regent of Karo No. 35 of 2016 aboutthe Position, Organizational Structure, Duties and Functions, as well as the Working System of the Device Area, the Field of Counseling in the Department of Agricultural Karo is responsible for Unit of Institutional Agricultural Extension; Unit of Workforce Agricultural Extension; and Unit of Section Method and Information on Agricultural Extension. Management of agriculturalextension is needed to successfully achieve the goals, and some of the factors that affect the success of counseling consist of human resources (man), facility extension (machines), budget counseling (money), the extension method (method), and extension materials (materials). In the regulation, the Karo Regency has published Regulations of the Regent of Karo No. 28 of 2017 about the Commission of Agricultural Extension, Fisheries, and Forestry Karo signed by the Regent of Karo District on November $2^{\text {nd }}, 2017$, but in fact farmers in the Karo still not prosperousactivities of the farm. The results of agricultural enterprises that reliable of Karo Regency in the form of Cabbage Cabbage, Potatoes, Turnips, Carrots, Peppers, Tomatoes, green onions, Corn, Citrus, Passion fruit, and so on.[8]

Article 5 of Government Regulation No. 43 of 2009 on the Financing, Development, and Supervision of Agricultural, Fisheries, and Forestry Extension, as well as Article 2 of Presidential Regulation No. 154 of 2014 concerning Institutional Extension of Agriculture, Fisheries, and Forestry, regulates: At the national level, there is an extension agency; at the provincial level, there is a coordinating board of counseling; at the district level, there is an extension agency; at the district level, there is an extension hall; and at the village / village level, there is an extension post.[9] Through the agricultural extension activities, the farmers are expected to gain knowledge and important information related to farming practices that better, knowing how the marketing of the business products agriculture with better, knowing the development of the prices of agricultural products every day, knowing how to obtain and produce fertilizer and seeds that are better, and if possible also know the business of agroindustry to add value to agricultural products following with the development needs of the community.

Article 345 paragraph 2 letter E of the Local Government Law No. 32 of 2014 regulates: management of public services that must be built by the local government, one of which is 
community counselling. Between the farmers with the makers of the policy area, there is an agricultural extension position as a communications liaison between the farmers, to disseminate information from the center for research agriculture to farmers, or conveys the aspirations of thepeasants to the government, because the position of the agricultural extension workers conducting face-to-face directly with the farmers to know the situation and the conditions that the actual about agriculture in the Karo Regency. Resources agricultural extension in Karo District is very limitedand needs to be improved, and this leads to the plans and objectives of agricultural extension doesnot run with the maximum.

By officials in Karo District, the construction of the field of agriculture is often not efficient and effective to be given special attention due to its capital base large, but the expected results do not directly appear/are perceived as well as the many risks that lead to failures such as natural factors, technological factors, factors seeds, and so on.[10] This leads to a discussion of the issues of agricultural development that did not attract the attention of local officials, especially inKaro Regency better it was in part legislative and executive. Other business sectors such as mining, industry, tourism, and the exploration of forestry have faster results compared to agricultural activities. Article 4 paragraph 1 of Government Regulation No. 43 of 2009 Concerning Agricultural, Fisheries, and Forestry Extension Finance, Construction, and Supervision, regulates: Institutional operational costs of extension; Operating expenses of civil servant extension; Procurement and maintenance costs of facilities and infrastructure; The cost of professional benefits for extensionists who have qualified competence and do counseling are all included in the financing of extension implementation. The Karo District Agricultural Office's budget and work plan for extension in 2020 includes the following:[11]

1. Package follow the Events Counseling, specialized clothing shopping 26 participants PENAS KTNA XVI, Rp.13.000.000.-

2. Package construction/repair extension institute of agriculture in the District and the provision of means of support counseling form:

a. Shopping 12 units of measure content of the soil amounted to Rp.62.381.474.-

b. Shopping 13 units of the procurement of two-wheeled vehicles andRp.414.063.000.-

c. Shopping 56 units work table official Rp.66.567.256.-

d. Shopping 10 computer unit Rp.127.990.000.-

e. Shopping renovation of 1 unit of agricultural hall District of Barus Rp.101.000.000.-

f. Shopping renovation of 1 unit of agricultural hall District of Namanteran Rp.106.000.000.-

g. Shopping renovation 12 units agricultural hall District of Simpang Empat Rp.220.000.000.-

3. Package follows the events counseling form:

a. Shopping 1 set of tools and supporting materials of the exhibition PENAS KTNAXVI Rp.3.746.400.-

b. Shopping 1 set shopping stationery Rp.7.963.800.-

c. Shopping 1 set shopping print Rp.1.902.800.-

d. Shopping for a 16 day hire mobility of the army of Rp.24.912.000.-

e. Shopping 200 sets of official travel outside of the Province of participants PENAS KTNA XVI Rp.95.875.000.-

4. Package construction/repair extension institute of agriculture in the District and the provision of means of support counseling in the form of shopping consumables 4 piecesof the computer and the printer Rp.718.000.- 
5. Package procurement of facilities and infrastructure counseling in the form of shopping 274 fruit print workbook extension semesters 1 and 2 Rp.18.445.132.-

6. Package to improve the capacity of extension workers and agricultural specialized:

a. Shopping for 81 people help the allowance of participants amounted to Rp4.050.000,-

b. Shopping 1 package of stationery Rp.8.124.170.-

c. Shopping 5 meters to print Rp. 300,000.-

d. Shopping 30 sheets for documentation of Rp.150.000.-

e. Shopping for 20 people services the speakers of Rp.13.200.000.-

f. Shopping 1 set for food and beverage training Rp.16.544.000.-

g. Shopping 6 copies shopping binding of Rp.90.000.-

h. Shopping 8.592 sheet photocopy similar to Rp.3.436.800.-

i. Shopping 1 set of rental money meeting of Rp.20.299.530.-

7. Package to improve the ability of Institutions of farmers, in the form of:

a. Shopping 1 set of goods to be delivered to the winner of the award of agricultural extension Rp.37.334.230.-

b. Shopping 1 person honorarium commission of agricultural extensionRp.1.000.000.-

c. Shopping 1 set honorarium commission of agricultural extension Karo Rp.4.300.000.-

8. Package the provision of personnel services administrative support/technical office in the form of:

a. Shopping for 1.164 people facilities money working the guidance of agricultural extension Rp.582.000.000.-

b. Shopping for 192 people honorarium honorary employee of agricultural extension Rp.403.200.000.-

c. Shopping for 90 people honorarium daily workers off of agricultural extension Rp.96.300.000.-

See the number of the very large budget of the Department of Agriculture Karo special implementation of agricultural extension, the government should be more serious and a maximumof doing agricultural extension is good and right, not only impressed just executing that budget isused up. Agricultural land in the Karo Regency of 212.725 ha with farmers as much as 76.727 people spread across 17 districts as follows:[12]

1. District Mardinding of 26.711 ha with corn, rice, hazelnut, number of farmers 4.265 people.

2. District Laubaleng of 25.260 ha with corn, rice, hazelnut, number of farmers 4.512 people.

3. District Tigabinanga of 18.700 ha with corn, rice, hazelnut, cocoa, the number of farmers 4.912 people.

4. District Juhar of 21.856 ha with corn, rice, hazelnut, number of farmers 4.730 people.

5. District Munthe of 12.564 ha with corn, rice, pepper, cabbage number of farmers 5.655 people.

6. District Kutabuluh of 19.570 ha with corn, peanuts, sweet potatoes, oranges, the numberof farmers 4.158 people.

7. District Payung covering an area of 5,500 ha of maize, rice, garlic, tomatoes, onion leaves, the number of farmers is 2.971 people.

8. District Simpang Empat of 9.363 ha with corn, long beans, sweet potatoes, potatoes, cabbage, chili, carrots, tomatoes, oranges, passion fruit black, the number of farmers 5.408 people.

9. District Kabanjahe of 4.465 ha with corn, sweet potato, potatoes, chili peppers, oranges, the 
number of farmers 6.252 people.

10. District Berastagi area 3.050 ha with commodity cabbage, carrots, tomatoes, oranges, corn, potatoes, sweet potatoes, chili, passion fruit, leaves sop, the number of farmers 4.154 people.

11. District Tigapanah of 21.909 ha with commodities sweet potato, potato, chili, cabbage, carrot, grapefruit, eggplant Netherlands, the number of farmers 7.390 people.

12. District Merek of 12.551 with commodities sweet potatoes, potatoes, leeks, onions, peppers, cabbage, citrus, the number of farmers 4.050 people.

13. District Barusjahe of 12.804 ha with potato, cabbage, tomatoes, oranges, the number of farmers 6.654 people.

14. District Merdeka of 4,400 hectares with corn, sweet potato, potato, cabbage, chilipeppers, oranges, tomatoes, passion fruit, leek, lettuce, carrots, number of farmers 2.295 people.

15. District Naman Teran of 8.782 ha with corn, sweet potato, potato, cabbage, chili peppers, oranges, tomatoes, passion fruit, the number of farmers 3.385 people.

16. District Tiganderket of 7.870 ha of maize, rice, tomato, pepper, tobacco, the number of farmers 3.709 people.

17. District of the Sovereign People of 3.235 ha with commodities sweet potato, potato, chili, cabbage, carrot, grapefruit, the number of farmers 2.227 people.

As mentioned in the official website of the Government of Karo Regency, recognizing some of the weaknesses and threats to agriculture in the form of the Number of Employees of Agricultural Extension (PPL) are still lacking and the ability PPL are still inadequate, and the development of agricultural technology very rapidly throughout the world, so that the efficiencybecomes higher from time to time, so that agricultural activities in the District of Karo will be threatened with agricultural products from outside if not able to follow the development of technology and farm management is active continuously. While on the other hand, there are chances of agriculture in the form of agricultural products Karo still have opportunities in the market both national and international levels, as well as the distribution and amount of agriculturalequipment on the market, are still enough for agricultural development.

Therefore, the government Drafted a plan: Carry out revitalization and intensification of agriculture, enhance the product competitiveness of agriculture through organic farming and the agro-politan program of the plateau, cooperates with outside parties to improve the ability of the technology, the develop of information networks and business partners to build the market for theproduction of agricultural Karo, build and open a network of roads to the center - centers of agricultural production, build an agro-politan Area to support the improvement of agriculture, build supporting facilities development/breeder plant seeds and agricultural training, provide appropriate technologies to improve the competitiveness of agricultural products.[13]

Aside from the above, the obstacles faced by the government of Karo Regency in particular to the development of agriculture in the Karo Regency is the motivation for the publicto acquire new knowledge is still low, bank lending to farmers is still a little bit, ethos and discipline of the working apparatus of the government are still low and the poor, the working units in the Government of Karo Regency is still yet to establish good communication with stakeholdersso that the work plan and the policy has not hit the target, management information system is still lacking, farmer groups yet powerful and independent so it does not have the capacity entering the market as well as open access to banking, human resources, farmers are still low, the managementand procurement of supporting facilities for agricultural production is inadequate, there are still alot of agricultural lands has not certified the status of its ownership. 


\section{Conclusion}

The implementation of agricultural extension in the Karo still not balanced between the elements of the government as the civil society with the number of farmers that amounted to tens of thousands of farmers who cultivate hundreds of thousands of hectares of agricultural land. It has caused a lot of obstacles as submitted in the above explanation, and the condition of the coursewill run continuously and cause a decrease in the quality of agricultural production in Karo District, and will certainly cause a great loss to Karo and reduce revenue because above $75 \%$ of the population Karo livelihood as farmers. Obstacles that arise related to the implementation of counseling agriculture became the responsibility of the Government of Karo Regency as the party that leads Karo to be solved by drawing up plans, budget, good supervision from time to time to implement it in the middle of people's lives by the apparatus of the Government of Karo Regency, to improve services to the community, to get the ratio of high-to-income native to the area and the availability of supporting facilities for agricultural production throughout the district that are in the Karo Regency.

Advice to the government of Karo Regency, to immediately realize the implementation of the revitalization and intensification of agriculture, increased product competitiveness of agriculture through organic farming and the agro-politan program of the plateau, collaborates withoutside parties in improving the ability of the technology, the development of information networks and business partners to build the market for the production of agricultural Karo, accelerate the construction of a network of roads to the center - production center of agriculture, to oversee the construction of the center agro-politan Area in supporting the improvement of agriculture, immediately build supporting facilities development/breeder plant seeds and agricultural training, and accelerate the provision of appropriate technologies to improve the competitiveness of agricultural products, fiber improves the work ethic of the apparatus of the government of Karo Regency in serving the community.[14]

Advice to farmers in Karo District, increase the motivation to accept new knowledge in the field of agriculture, discipline and more care in keeping the environment into agriculture to awake the preservation of the natural resources necessary for agriculture, the teachings of religion and culture were positive in life - day, forming farmer groups as a forum for the exchange information exchange about agriculture, and adopt technology equipment, seed, fertilizer appropriate for agricultural production remained in good quality with the quantity according to the demand of society as consumers.[15]

\section{Acknowledgement}

In compiling this journal, many people have provided motivation, advice, and support for the author. On this precious occasion, the author intends to express his gratitude and appreciation to all of you who have provided moral and material support. In the end, I would like to thank every one's who was instrumental in the successful realization of this journal. This journal is far from perfect but is expected to be useful not only for authors, but also for readers to add insight into the field of Law. therefore, constructive suggestions and criticisms are expected for the improvement of this journal.

\section{References}


[1] Presidential Regulation Number 154 of 2014 concerning Agricultural, Fisheries and Forestry Extension Institutions.

[2] Law Number 16 of 2006 concerning Agricultural, Fisheries, and Forestry Extension Systems.

[3] Law Number 23 of 2014 concerning Regional Government.

[4] Karo Regent Regulation Number 35 of 2016 concerning Position, Organizational Structure, Duties and Functions as well as working procedures of regional apparatus.

[5] Kusnadi, Dedy. Dasar-Dasar Penyuluhan Pertanian. Sekolah Tinggi Penyuluha Pertanian Bogor, Bogor (2011)

[6] Budi, Setia. Penyuluhan Pertanian: Teori dan Penerapannya. Sefa Bumi Persada, Lhokseumawe (2018)

[7] Gitosaputro, Sumaryo. Dinamika Penyuluhan Pertanian: dari era colonial sampai dengan era digital. CV Anugrah Utama Raharja, Bandar lampung (2018)

[8] Regent Regulation Number 28 of 2017 concerning the Karo Regency Agricultural, Fisheries and Forestry Extension Commission.

[9] Government Regulation Number 43 of 2009 concerning Financing, Guidance, and Supervision of Agricultural, Fisheries and Forestry Extension Officers.

[10] https://karokab.bps.go.id/subject/154/pertanian.html\#subjekViewTab3

[11] https://www.karokab.go.id/id/attachments/article/8849/RUP_DinPertanianKKaro2020 Rev1.pdf

[12] https://www.karokab.go.id/id/profil/program-pembangunan-daerah

[13] Sirnawati, Enti. 2020. The Urgency of New Agricultural Extension in Indonesia. Jakarta: IAARD PRESS.

[14] Harahap, Nurliana. Evaluasi Penyuluhan Pertanian. Badan Penyuluhan dan Pengembangan SDM Pertanian, Jakarta (2017)

[15] http://epublikasi.pertanian.go.id/epublikasi/statistik\%20sdm\%20dan\%20kelembagaan/2 019/Statistik_SDM_Pertanian_dan_Kelembagaan_Petani_2019/files/assets/basic$\mathrm{html} /$ page $43 . \mathrm{html}$ 